\title{
ITS sequence data and morphology differentiate Cytospora chrysosperma associated with trunk disease of grapevine in northern Iran
}

\author{
Mahdi Arzanlou*, Abolfazl Narmani
}

Plant Protection Department, Faculty of Agriculture, University of Tabriz, P.O. Box 5166614766, Tabriz, Iran

Received: October 10, 2014

Accepted: March 16, 2015

\begin{abstract}
Trunk diseases are potential threats for the grapevine industry owing to the worldwide incidence and economic impact of the diseases. Several fungal groups are known to be involved in these diseases. In a survey on grapevine trunk diseases in northern Iran, Cytospora isolates were repeatedly recovered from vines showing decline symptoms. The symptoms appeared as pale brown to brown streaks in longitudinal cuts of shoots. The morphological and cultural characteristics of the isolates were in agreement with the description of Cytospora chrysosperma. Sequence data of the ITS-rDNA region was used to further confirm the identity of the species. Phylogenetic analysis based on the sequence data obtained in this study and the sequences from GenBank, confirmed the morphological identification. Our isolates were clustered together with C. chrysosperma isolates known from other woody host plant species. The pathogenicity assay on detached shoots of grapevines induced the same symptoms as was observed in field conditions. Although, C. chrysosperma is known from several woody hosts in Iran, the occurrence of this species on grapevines showing decline symptoms is new. The economic impact, distribution, and degree of involvement of C. chrysosperma in decline of vines in other regions of Iran remains to be studied.
\end{abstract}

Key words: brown streaks, decline, ITS-rDNA, perennial canker, Valsa sordaria

\section{Introduction}

The Iranian grapevine industry plays a significant role in the country's economy. According to the statistics of the United Nations Food and Agriculture Organization (FAO), the Iranian grapevine industry presently covers a total area of 286,000 ha, with an annual production of $3,000,000 \mathrm{t}$ (FAO 2012). The Iranian viticulture system is mainly traditional. The establishment of new vineyards is done differently compared to other countries. In Iran, vineyards are routinely established by direct planting of rooted grapevine cuttings. The grafting process is not a common practice.

Grapevines are susceptible to a large variety of devastating diseases caused by fungi, bacteria, viruses, and other biotic and abiotic agents. Trunk diseases constrict grapevine cultivation and vineyard productivity and longevity in many countries (Mugnai et al. 1999; Mostert et al. 2006; Arzanlou et al. 2013a). The economic importance of trunk diseases on the grapevine industry led to the establishment of an international council on grapevine trunk disease (IGTD). The aim of IGTD is to promote collaboration and the exchange of information among scientists involved in research on grapevine trunk diseases. A biannual workshop is organized by the IGTD on grapevine trunk diseases. The 10th workshop on grapevine trunk diseases was held in November 2014, in Australia. The term fungal trunk diseases, is attributed to the group of diseases whose agents are located in the mature stem (trunk and cordons) of grapevines. Esca and related diseases caused by Phaeoacremonium and Phaeomoniella, represent historic and well-studied trunk diseases on grapevines (Mugnai et al. 1999; Mostert et al. 2006; Essakhi et al. 2008; Arzanlou et al. 2013a; Arzanlou et al. 2014). Other diseases are caused by such fungal pathogens as Eutypa, Botryosphaeria, Cylindrocarpon, and Phomopsis (Phillips 1998, 2002; Luque et al. 2005, 2006; Van Niekerk et al. 2004, 2005, 2011; Taylor et al. 2005; Alves et al. 2008; Trouillas and Gubler 2010; Arzanlou et al. 2012). Grapevine trunk diseases are generally considered to be complex diseases in which a combination of fungal groups are involved (Mostert et al. 2006). A brief overview on the etiologic agents of grapevine trunk diseases is presented in table 1. In recent years, several other fungal groups have been characterised from grapevines with trunk disease symptoms, including: Cadophora luteo-olivacea, Macrophomina phaseolina, Pestalotiopsis uvicola, Verticillium dahliae, Phomopsis viticola, Truncatella angustata, Fusarium spp., Cytospora spp., and Acremonium spp. However, the contribution and degree of involvement for many of the abovementioned fungal groups in trunk-disease progress on grapevines remain unknown and their pathogenicity on grapevines still need to be tested (Trouillas and Gubler 
Table 1. Fungal species known as the etiologic agents of grapevine trunk diseases

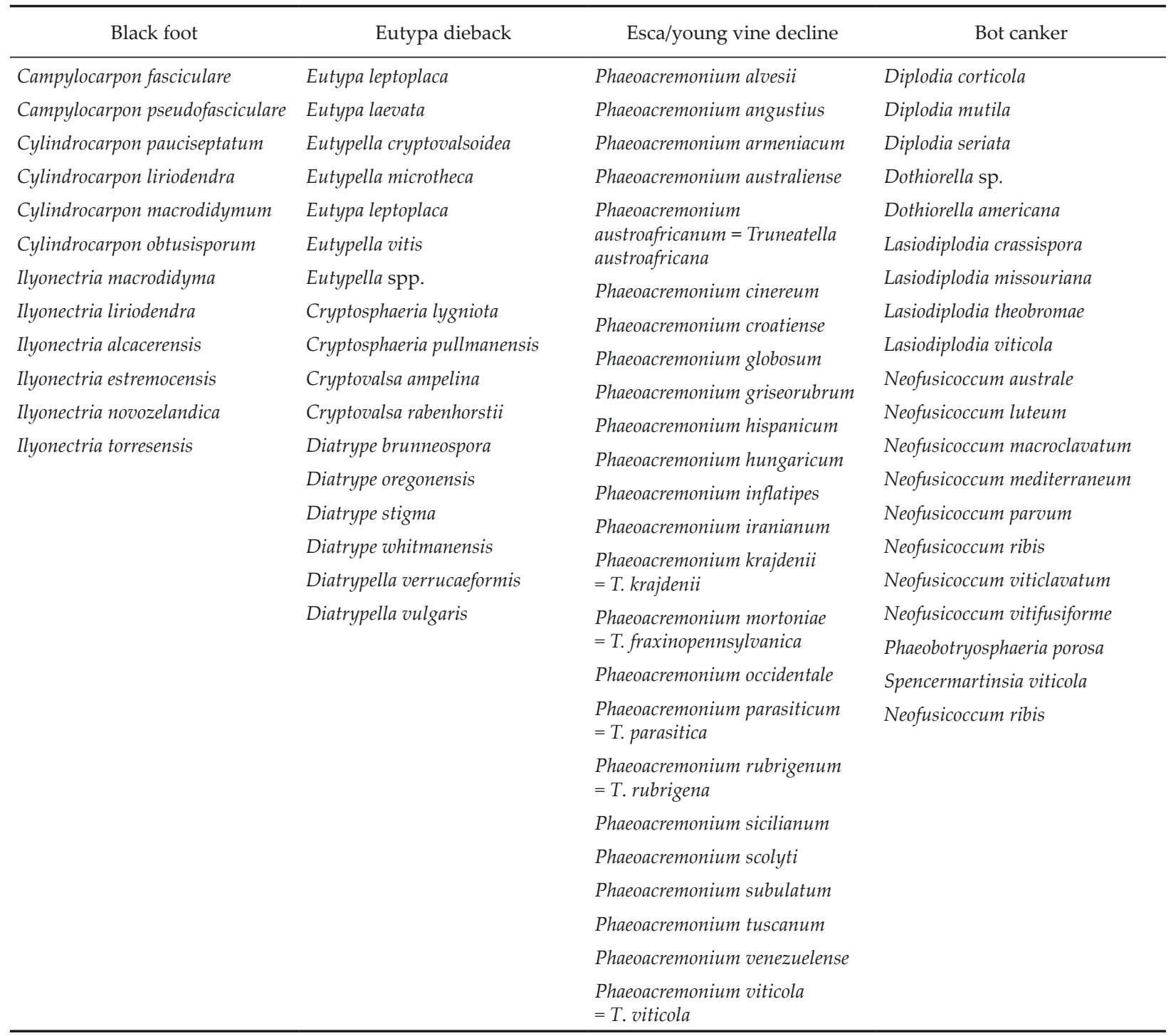

2010; Arzanlou et al. 2012; Arzanlou et al. 2013b; Arzanlou et al. 2014).

Species of the genus Cytospora are generally known as the causal agents of canker (referred to as Valsa canker, Leucostoma canker or perennial canker) and dieback on woody host plant species, with rare occurrences on herbaceous plants. Over 85 woody hosts have been listed as susceptible to Cytospora canker including many economically important fruit trees as well as shade and ornamental tree species in different stages of growth (Sinclair et al. 1987; Fotouhifar et al. 2007, 2010). Cytospora canker is considered to be a destructive disease on stone fruit trees especially on peach (Barakat and Johnson 1997). The pathogens infect the inner bark (secondary phloem) and the outer bark (periderm) (Adams et al. 2005, 2006). Some of the Cytospora spp. are known to have an endophytic life style, colonising xylem tissues in healthy woody hosts (González and Tello 2011).

A number of Cytospora spp. are known to have a wide host range, occurring on a diverse range of plant species e.g. C. chrysosperma and C. cincta; while others are restricted to members of one plant family or a genus e.g. C. sacchari and C. tritici (Adams et al. 2005, 2006). There is a lack of knowledge on the occurrence and contribution of $C y$ tospora species in grapevine trunk diseases worldwide. González et al. (2011) have listed C. chrysosperma as an endophyte colonising grapevine woody tissues in Spain.

Several fungal species have been reported to occur on grapevines in Iran and have been reviewed by Arzanlou et al. (2013a). The first aim of this study was to characterise Cytospora spp. associated with grapevine canker disease in northwestern Iran by means of morphological and molecular data. The second aim was to further evaluate the pathogenicity of the agents using a detached shoot assay.

\section{Materials and Methods}

\section{Isolates and morphology}

Wood samples were collected from grapevines with decline symptoms. The symptoms included stunted growth, leaf yellowing and necrosis, internal wood necrosis, black vascular streaking or discoloured tissues (Figs. 1 and 2). The samples were collected in vineyards of the northwestern zone of Iran including the East and West Azerbaijan provinces. Isolation was made following the proto- 

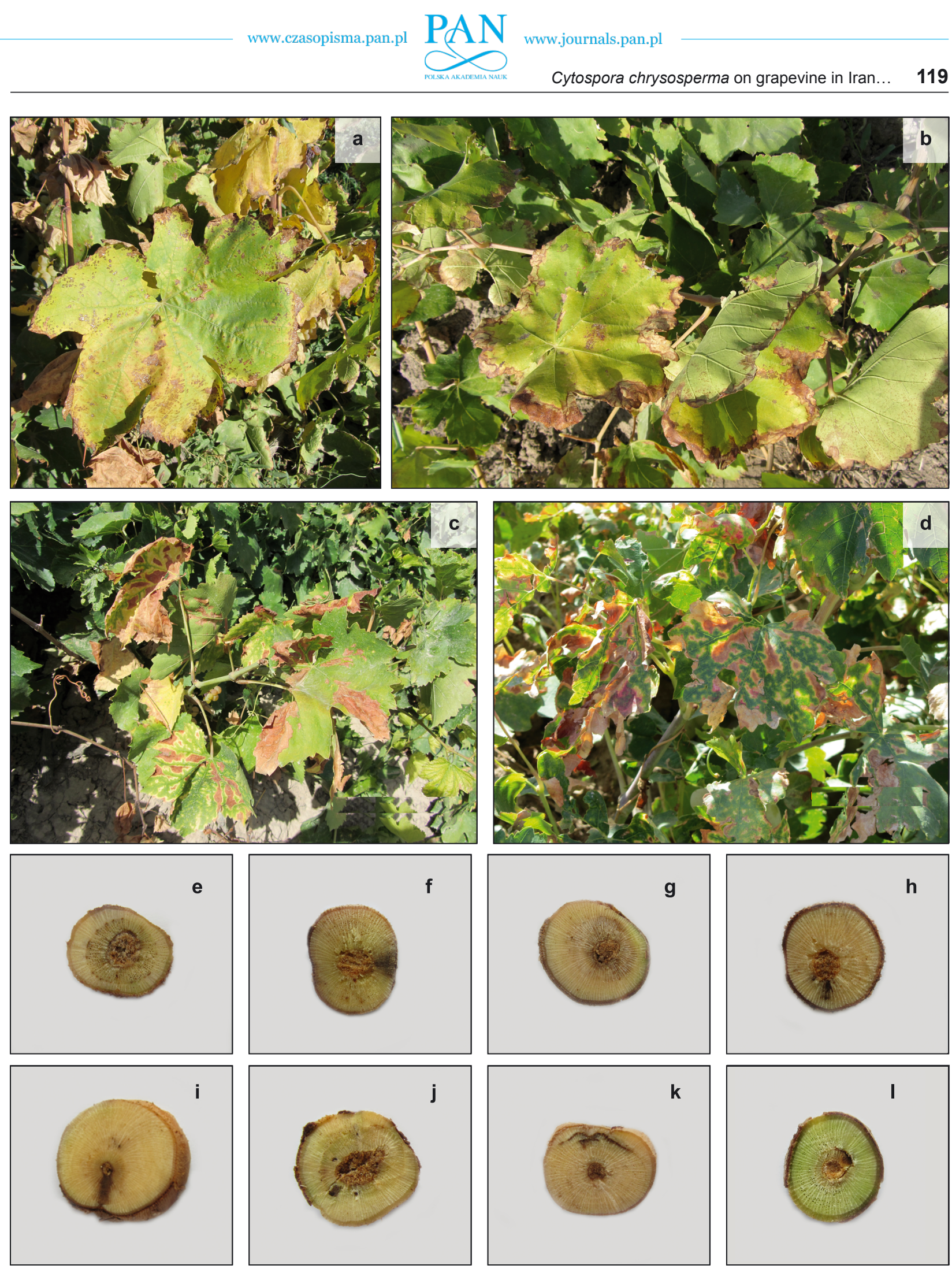

Fig. 1. External and internal decline symptoms on grapevines from which only Cytospora chrysosperma was recovered: a-d - stunted growth and leaf necrosis in a vineyard; e-1 - various types of wood necrosis and discolouration in cross sections through the wood

col described by Arzanlou and Dokhanchi (2013a, b), and Arzanlou et al. (2012, 2013a, b, 2014). In brief, small pieces, approximately $0.5 \times 0.5 \times 0.5 \mathrm{~cm}$, were cut from the discoloured wood tissues and surface-sterilised for 15-20 sec in $70 \%$ ethanol, rinsed three times with sterile water, dried on sterile filter paper, and transferred to Potato Dextrose Agar (PDA, Fluka, Hamburg, Germany) plates supplemented with $100 \mathrm{mg} \cdot 1^{-1}$ streptomycin sulphate and $100 \mathrm{mg} \cdot \mathrm{l}^{-1}$ ampicillin. Pure cultures were established by employing the hyphal tip technique. The cultures were preserved on PDA in $2 \mathrm{ml}$ microtube slants at $4^{\circ} \mathrm{C}$ in the Culture Collection of Tabriz University (CCTU). The morphological characteristics were examined based on pure cultures. Colony morphology, including colour, shape, and growth rate, was determined after 7 days of incubation on PDA at $25^{\circ} \mathrm{C}$ in darkness. Microscopic characters were studied using a smash mount technique with sterile distilled water, as explained by Arzanlou et al. 

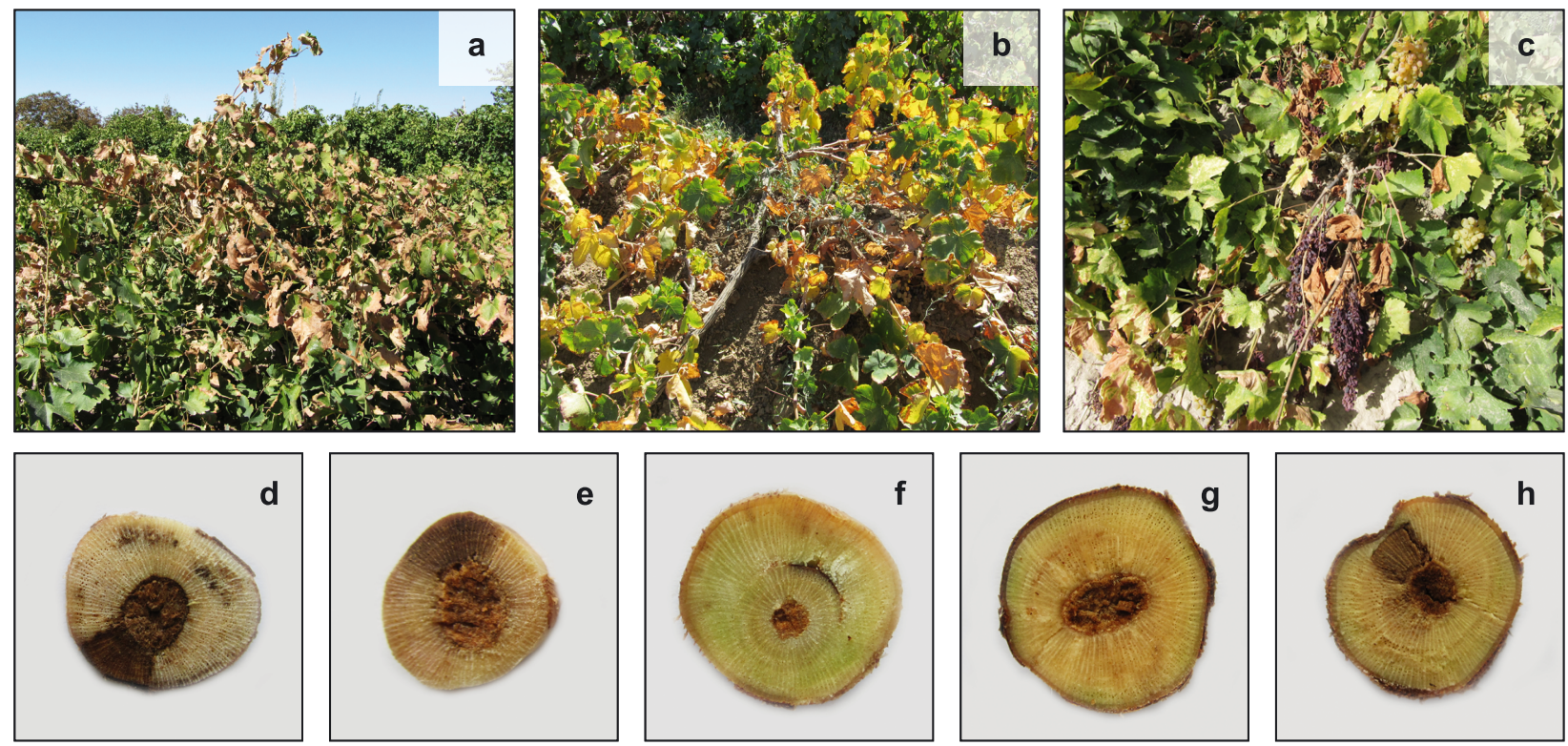

Fig. 2. External and internal decline symptoms on grapevines from which together with Cytospora chrysosperma other fungal trunk pathogens were also recovered: $\mathrm{a}-\mathrm{c}-$ stunted growth and leaf necrosis in a vineyard; $\mathrm{d}-\mathrm{h}-$ various types of wood necrosis and discolouration in cross sections through the wood

(2007). The dimensions of microscopic structures were calculated based on 30 measurements for conidia morphology (shape, colour, and cell number) and size (length and width) where possible.

\section{Molecular identification}

\section{DNA extraction}

For DNA extraction, fungal isolates were grown on PDA for 8 days in the dark. Fresh mycelia were collected and subjected to DNA extraction by using the protocol of Moller et al. (1992).

\section{Sequence analysis}

The ITS (International Transcribed Spacer) region, including the 3 ' end of the $18 \mathrm{~S}$ rRNA gene, ITS1, 5.8S rDNA, ITS2, and the $5^{\prime}$ end of $28 \mathrm{~S}$ rRNA gene, was amplified using the primer set V9G (Vilgalys and Hester 1990) and ITS4 (White et al. 1990). The reaction mixture was the same as for that of Arzanlou and Dokhanchi (2013a, b), Arzanlou and Khodaei (2012). The reaction was performed on a GeneAmp PCR System 9700 (Applied Biosystems, Foster City, CA) with cycling conditions consisting of $5 \mathrm{~min}$ at $96^{\circ} \mathrm{C}$ for primary denaturation, followed by 40 cycles of denaturation at $94^{\circ} \mathrm{C}$ for $30 \mathrm{sec}$, annealing at $52^{\circ} \mathrm{C}$ for $30 \mathrm{sec}$, extension at $72^{\circ} \mathrm{C}$ for $60 \mathrm{sec}$, with a final extension at $72^{\circ} \mathrm{C}$ for $7 \mathrm{~min}$. Sequencing of the Polymerase Chain Reaction (PCR) products was done using BigDye Terminator v3.1 (Applied Biosystems, Foster City, CA) Cycle Sequencing Kit according to the manufacturer's recommendation. The analysis was done on an ABI Prism 3700 (Applied Biosystems, Foster City, CA). Raw sequence files were edited manually by using SeqMan ${ }^{\mathrm{TM} I I}$ (DNASTAR, Madison, Wisconsin, USA), and a consensus sequence was generated for each of the sequences. Sequences were subjected to a Megablast search analysis at NCBI's GenBank nucle- otide database for sequence similarity. Sequences with a high similarity were downloaded from GenBank. The sequences were aligned by using ClustalW algorithm implemented in MEGA 5 (Tamura et al. 2011). The automatically aligned file was further checked by eye. A minimum number of gaps were inserted to improve the alignment. Phylogenetic trees were constructed using neighbour-joining method with the following criteria: substitution model as Jukes-Cantor; gap treatment as pairwise deletion and transitions and transversions (with the equal ratio). The supports of the internal nodes of the trees were evaluated by the bootstrap method with 10,000 replicates. Diaporthe eres CBS 267 (GenBank accession number: KC343081.1) was used as outgroup in the phylogenetic analyses.

\section{Pathogenicity studies}

Excised shoot assay was used to evaluate pathogenicity of the isolates in laboratory conditions as described by Arzanlou et al. (2012). In brief, 1-year old shoots, 10-15 mm in diameter and $25 \mathrm{~cm}$ in length, were cut from a healthy mature vein of cv. Askari. The leaves were removed and shoots were surface-sterilised with $70 \%$ ethanol. For inoculation, shoots were wounded $10 \mathrm{~cm}$ above the first internode by removing the cortex with a sterile $5 \mathrm{~mm}$ diameter metal cork borer. A mycelial plug (5 mm diameter) obtained from the margin of a seven-day-old fungal colony was placed in the wound with the mycelium facing the stem. The wound was wrapped with Parafilm and for the control shoot a plug of MEA was placed in the wound. Inoculated shoots were placed in a plastic container containing moistened filter papers to keep the relative humidity high. The shoots in the containers were kept in laboratory conditions at $25^{\circ} \mathrm{C}$ with natural daylight. Shoots were examined after 28 days for disease progress. Longitude sections were made going upward and downward from the inoculation point with C. chrysosperma isolate. The length of necrosis was used as an indicator of pathogenicity. The 
experiment was carried out using four fungal isolates and three replicates for each treatment.

\section{Results}

\section{Disease symptoms}

The symptoms on grapevines appeared as typical decline symptoms. The symptoms included stunted growth, dieback and leaf chlorosis, and necrosis. Internal symptoms appeared as different degrees of wood discolouration in the transverse section though brown wood discoloura- tion in sapwood was evident. From the symptoms presented in figure 1 , only $C$. chrysosperma was recovered. From the symptoms shown in figure 2 , besides $C$. chrysosperma, other fungal trunk pathogens were also isolated.

\section{DNA phylogeny and morphology}

Phylogeny inferred using the sequence data of the ITS-rDNA region from the isolates obtained in this study (Table 2), with other Cytospora spp. from GenBank, clustered our isolates with C. chrysosperma (100\% bootstrap support value) (Fig. 3).

Table 2. The list of Cytospora chrysosperma isolates used for phylogenetic analysis in this study

\begin{tabular}{cc}
\hline Collection number & Country of origin \\
\hline a CCTU153 & ' WA, Iran \\
CCTU154 & WA, Iran \\
CCTU155 & WA, Iran \\
CCTU156 & WA, Iran \\
CCTU383 & WA, Iran \\
CCTU400 & WA, Iran \\
CCTU401 & WA, Iran \\
CCTU402 & WA, Iran \\
CCTU405 & WA, Iran \\
CCTU406 & WA, Iran \\
\hline
\end{tabular}

${ }^{\mathrm{a}}$ Culture Collection of Tabriz University, Iran; ${ }^{\mathrm{b}}$ West Azerbaijan province

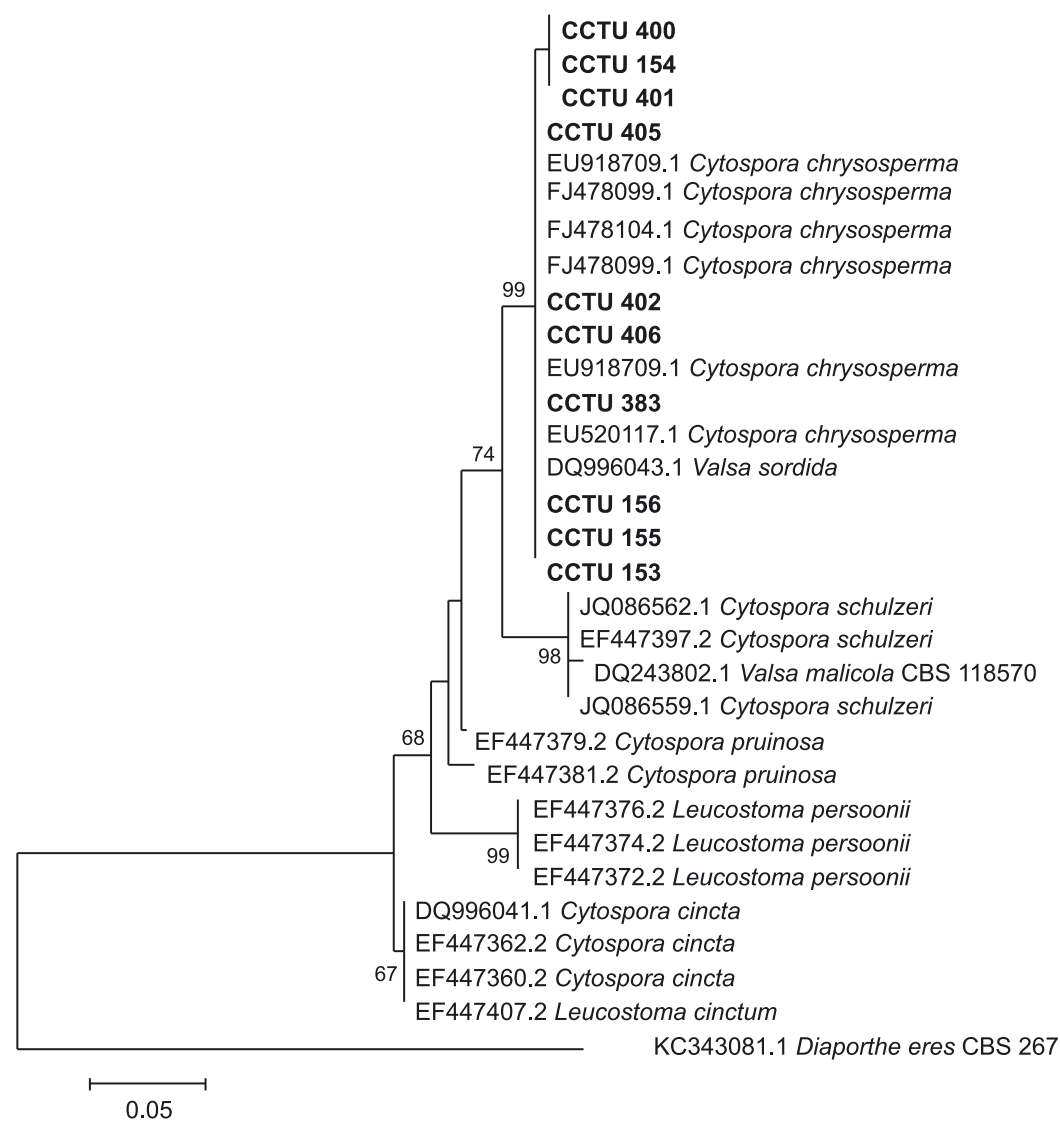

Fig. 3. A neighbour-joining phylogenetic tree obtained from the ITS region and 5.8S rDNA sequence data. Bootstrap support values (> 65) from 1,000 replicates are indicated on the nodes. The tree was rooted to Diaporthe eres (GenBank number: KC343081.1). The scale bar indicates 0.05 substitutions per site 
The cultural and morphological characteristics of our isolates were in full agreement with the description for C. chrysosperma (Adams et al. 2006). Colonies attained a diameter of $40 \mathrm{~mm}$ after 7 days of incubation at 25 on PDA. Colonies were flat to slightly raised, felty, and with entire margins. Colony colour on the surface was a moderate yellowish and on the reverse the colour was a moderate to strong yellow to moderate orange yellow. Conidiomata produced abundantly on PDA after two weeks of incubation. Conidiomata were scattered, labyrinthine cytosporoid, with labyrinthine chambers, circular to ovoid, 1-2 $\mathrm{mm}$ in diameter. Locules were multi-chambered, and often irregular. Conidiophores were hyaline, and of two types. Type 1 were branched and septate, $15-30 \mu \mathrm{m}$ in length. Type 2 were long, unbranched, and aseptate or rarely septate. Conidiogenous cells were phialidic, subcylindric, and hyaline. Conidia were hyaline, allantoid, and aseptate, 3.5-5(4) $\times$ $\times 1 \mu \mathrm{m}$, oozing out as an orange mucilaginous mass (Fig. 4).

\section{Pathogenicity studies}

The results of the pathogenicity assay revealed that C. chrysosperma is pathogenic on detached shoots of grapevines. The shoots were examined after 28 days to note the progress of the disease. Longitudinal and cross sections were made from above and below the inoculation point. Wood necrosis was evident on the inoculated shoots. No obvious symptoms were observed in the control. After removing the bark, a superficial brown discolouration was observed up and down from the inoculation points. In cross sections through the inoculation points, there was some wood discolouration apparent in some cases. There were substantial differences among the isolates in the length of lesions induced on shoots. The isolates D and C induced the largest lesion areas on detached shoots with a mean value of $12 \pm 2.64$ and $12.33 \pm 1.2 \mathrm{~cm}$, respectively; while, the lengths of the lesion induced by isolates $\mathrm{A}$ and $\mathrm{B}$ were $6.50 \pm 1.04$ and $7.16 \pm 1.01 \mathrm{~cm}$, respectively. Pycindia were developed on inoculated shoots. No fungal structure was observed on the control (Fig. 5). Koch's postulates were fulfilled by the re-isolation of the causal agents from the inoculated shoots. Cytospora chrysoperma was recovered only from the inoculated shoots. No fungal growth was observed in the controls (Fig. 5).
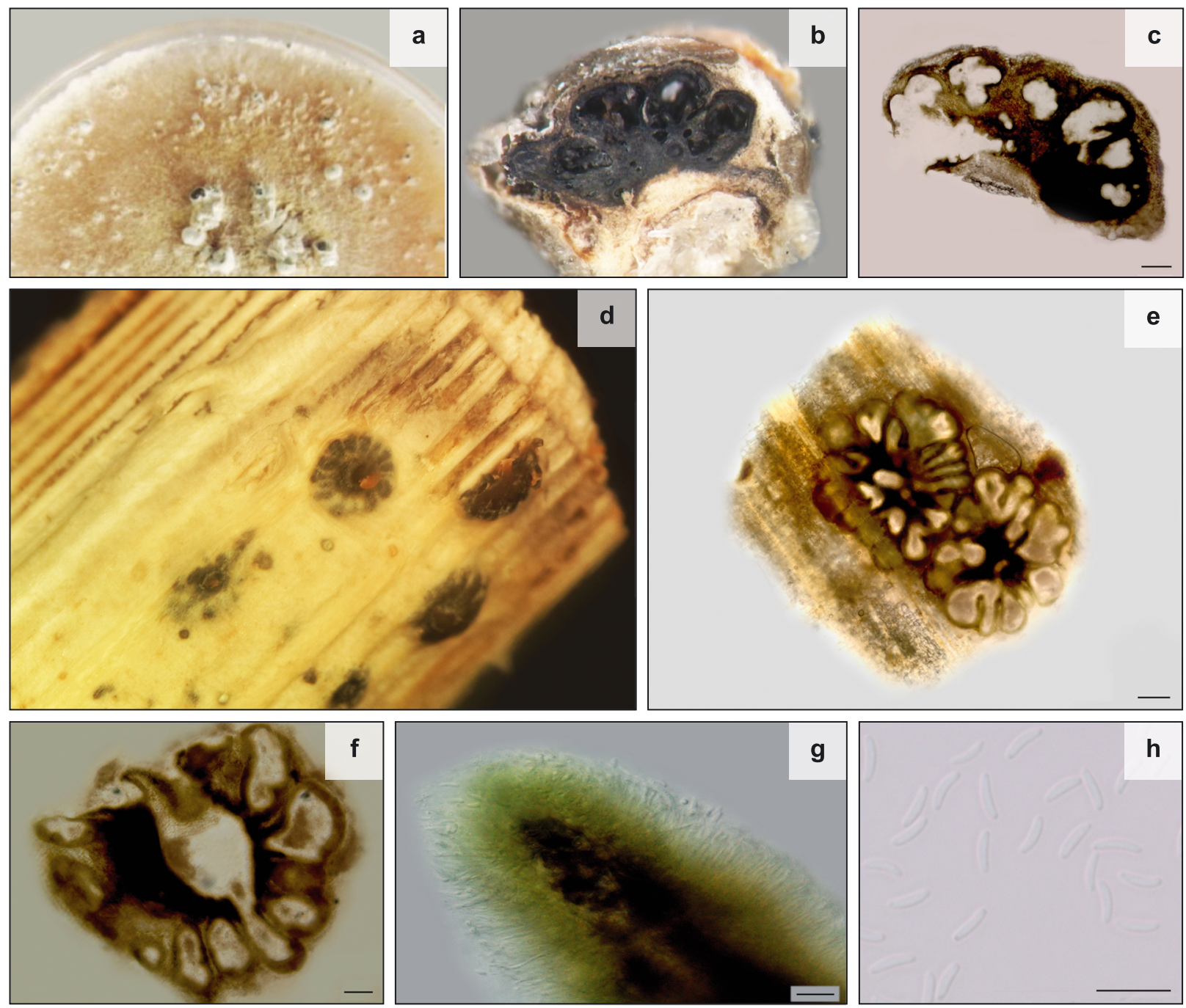

Fig. 4. Cytospora chrysosperma: a - colony morphology on PDA; b-c - cross section through conidiomata on PDA; $\mathrm{d}$ - conidiomata on bark of inoculated shoot; $\mathrm{e}-\mathrm{f}$ - cross section through conidiomata developed on artificially inoculated shoot; $\mathrm{g}$ - conidiophores; $\mathrm{h}$ - conidia. Scale bars: $\mathrm{c}, \mathrm{e}=200 \mu \mathrm{m} ; \mathrm{f}=100 \mu \mathrm{m} ; \mathrm{g}, \mathrm{h}=10 \mu \mathrm{m}$ 

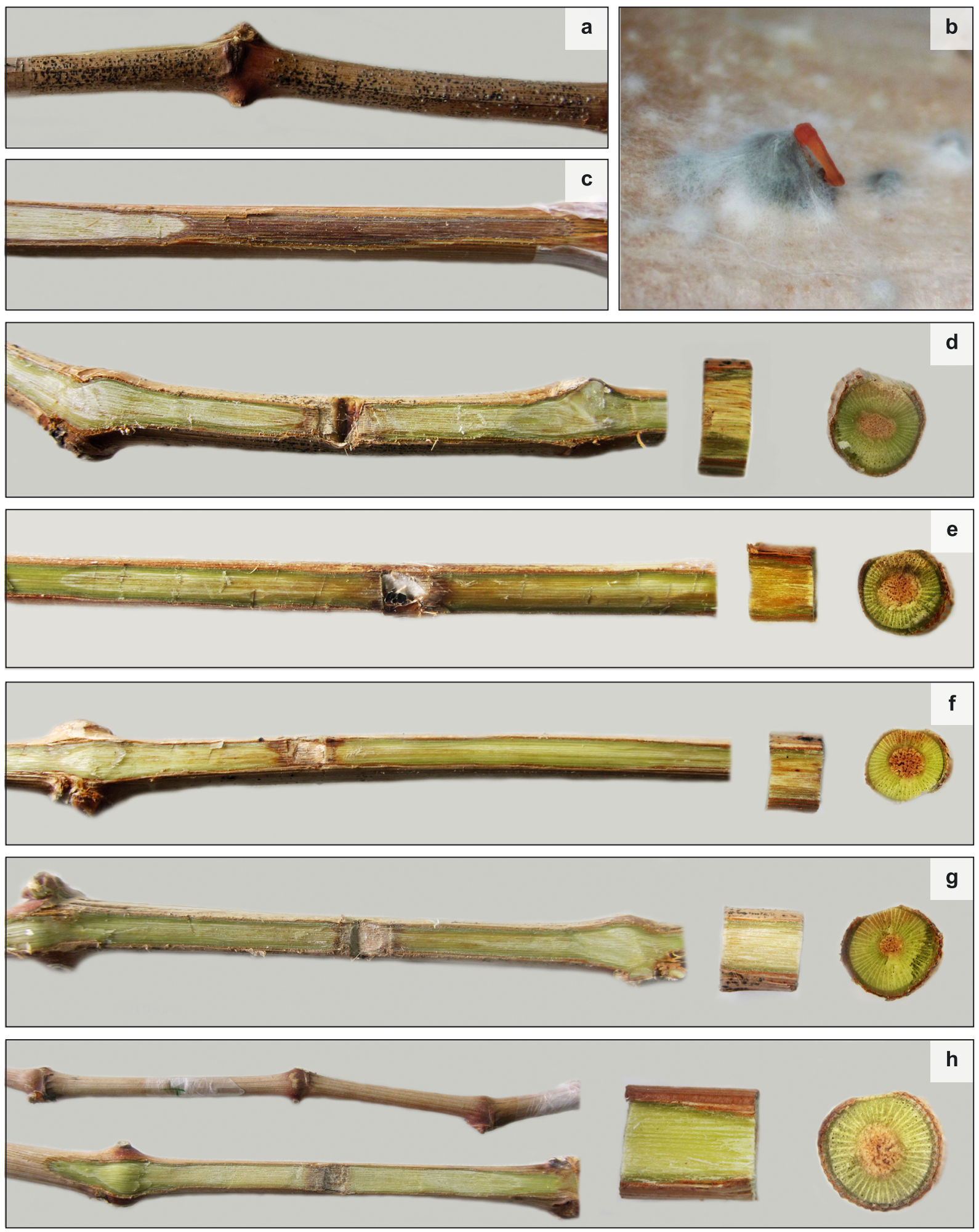

Fig. 5. Pathogenicity assay using excided shoot method: $\mathrm{a}-\mathrm{b}$ - pycnidium on inoculated shoot; $\mathrm{c}$ - superficial wood necrosis upward and downward from the inoculation point; $\mathrm{d}-\mathrm{g}$ - disease symptoms and discoloration on inoculated shoot with Cytospora chrysosperma; $\mathrm{h}$ - control with no obvious disease symptom

\section{Discussion}

Trunk diseases are among the most destructive diseases of vineyards worldwide. Several fungal groups have been noted on grapevines with trunk diseases symptoms (Table 1). In the present study, Cytospora isolates were isolated from grapevines displaying typical symptoms of decline including stunted growth, leaf chloro- sis and necrosis. The other fungal groups isolated from symptomatic tissues (Fig. 2) included Togninia minima (asexula morph: Phaeocremonium aleophilum) (Arzanlou and Narmani 2014), Fusarium spp., Acremonium spp., and Pestalotiod fungi. Various types of internal wood discolouration were observed in cross sections through the cane and trunk. Morphological and molecular char- 
acterization of Cytospora isolates revealed the identity of species as C. chrysosperma. Cytospora chrysosperma is known to have a wide host range with common occurrence on members of Salicaceae, and is rare on other woody angiosperms throughout the world (Gvritishvili 1982; Hayova and Minter 1998). Fotouhifar et al. (2007, 2010) have provided a list of the host plant species for C. chrysosperma in Iran. There are only a few reports on the occurrence of Cytospora species on grapevines. Fotouhifar et al. (2010) have reported C. cincta and C. leucostoma from grapevine in Iran. González and Tello (2011) have listed C. chrysosperma as an endophyte colonising grapevine woody tissues in Spain.

The inoculation studies carried out in this study, showed C. chrysosperma isolates being pathogenic on the excided shoot of grapevine. The results on the pathogenicity of Cytospora spp. are controversial. On Prunus (Biggs 1989) and Populus species (Kepley and Jacobi 2000), Cytospora species have proven to be highly virulent and destructive. However, in general, Cytospora species are considered as wound parasites attacking trees weakened by biotic and abiotic factors (Schoeneweiss 1975, 1983). Some of the species have an endophytic lifestyle colonising bark and xylem tissues of woody hosts (Fisher et al. 1993; Bills 1996).

After putting all of the results together, it can be said that $C$. chrysosperma is a potential pathogen on grapevine in Iran. Further studies on the host range, pathogenicity, and virulence of this species on different cultivars of Vitis vinifera are now required.

\section{Acknowledgements}

The authors would like to thank the Research Deputy of the University of Tabriz and the Studienstiftung Mykologische Systematik und Ökologie for their financial support.

\section{References}

Adams G.C., Roux J., Wingfield M.J. 2006. Cytospora species (Ascomycota, Diaporthales, Valsaceae): introduced and native pathogens of trees in South Africa. Australasian Plant Pathology 35 (5): 521-548.

Adams G.C., Wingfield M.J., Common R., Roux J. 2005. Phylogenetic relationships and morphology of Cytospora species and related teleomorphs (Ascomycota, Diaporthales, Valsaceae) from Eucalyptus. Studies in Mycology 52: 1-142.

Alves A., Crous P.W., Correia A., Phillips A.J.L. 2008. Morphological and molecular data reveal cryptic speciation in Lasiodiplodia theobromae. Fungal Diversity 28 (1): 1-13.

Arzanlou M., Dokhanchi H. 2013a. Phenotypic and molecular characterization of Diplodia seriata, the causal agent of canker and twig dieback disease on mulberry in Iran. Archives of Phytopathology and Plant Protection 46 (6): 682-694.

Arzanlou M., Dokhanchi H. 2013b. Calosphaeria canker of almond caused by Calosphaeria pulchella in Iran. Archives of Phytopathology and Plant Protection 46 (2): 215-226.

Arzanlou M., Khodaei S. 2012. Aureobasidium iranianum, a new species on bamboo from Iran. Mycosphere 3 (4): 404-408.

Arzanlou M., Moshari S., Bakhshi M., Khodaei S. 2012. First report of Botryosphaeria dothidea associated with grapevine decline disease in Iran. Australasian Plant Disease Notes 7 (1): 197-200.

Arzanlou M., Moshari S., Salari M., Badali H. 2013a. Molecular characterization and pathogenicity of Phaeoacremonium spp. associated with esca disease of grapevine in Northern Iran. Archives of Phytopathology and Plant Protection 46 (4): 375-388.

Arzanlou M., Narmani A., Moshari S., Khodaei S., Bababi-ahari A. 2013b. Truncatella angustata associated with grapevine trunk disease in Northern Iran. Archives of Phytopathology and Plant Protection 46 (10): 1168-1181.

Arzanlou M., Narmani A. 2014. Multiplex PCR assay for specific identification and determination of mating type applied to Togninia minima (anamorph known as Phaeoacremonium aleophilum), one of the causal agents of esca disease in grapevine. Phytopathology Mediterraneum 53 (2): 240-249.

Arzanlou M., Narmani A., Moshari S., Khodaei S. 2014. Pome and stone fruit trees as possible reservoir hosts for Phaeoacremonium spp., the causal agents of grapevine esca disease, in Iran. Archives of Phytopathology and Plant Protection 47 (6): 717-727.

Barakat R.M., Johnson D.A. 1997. Expansion of cankers caused by Leucostoma cincta on sweet cherry trees. Plant Disease 81 (12): 1391-1394.

Biggs A.R. 1989. Integrated approach to control Leucostoma canker of peach in Ontario. Plant Disease 73 (11): 869-874.

Bills G.F. 1996. Isolation and analysis of endophytic fungal communities from woody plants. p. 31-65. In: “Endophytic Fungi in Grasses and Woody Plants: Systematics, Ecology, and Evolution" (S.C. Redlin, L.M. Carris, eds.). APS Press, St. Paul, MN, USA, 321 pp.

Essakhi S., Mugnai L., Crous P.W., Groenewald J.Z., Surico G. 2008. Molecular and phenotypic characterization of novel Phaeoacremonium species isolated from esca diseased grapevines. Persoonia 21: 119-134.

FAO (Food and Agriculture Organization of the United Nations). 2012. FAO Statistical Databases.

Available at http://www.fao.org/

Fisher P.J., Petrini O., Sutton B.C. 1993. A comparative study of fungal endophytes from leaves, xylem and bark of Eucalyptus nitens in Australia and England. Sydowia 45 (2): 338-345.

Fotouhifar K.B., Hedjaroude G.A., Ershad D., Moussavi S.M., Okhovvat S.M., Javan Nikkhah M. 2007. New information on the form-genus Cytospora in Iran (I). Rostaniha 8 (2): 129-149.

Fotouhifar K.B., Hedjaroude G.A., Leuchtmann A. 2010. ITS rDNA phylogeny of Iranian strains of Cytospora and associated teleomorphs. Mycologia 102 (6): 1369-1382.

Gvritishvili M.N. 1982. The fungal genus Cytospora in the USSR. Izdatelstve Sabchota Sakarstvelo, Tbilisi, Russia, 214 pp.

González V., Tello M.L. 2011. The endophytic mycota associated with Vitis vinifera in central Spain. Fungal Diversity 47 (1): $29-42$.

Hayova V.P., Minter D.W. 1998. Leucostoma cinctum. IMI Descriptions of Fungi and Bacteria. Set 137 No. 1361, 3 pp.

Kepley J.B., Jacobi W.R. 2000. Pathogenicity of Cytospora fungi on six hardwood species. Journal of Arboriculture 26 (6): 326-332.

Luque J., Martos S., Phillips A.J.L. 2005. Botryosphaeria viticola sp. nov. on grapevines: A new species with a Dothiorella anamorph. Mycologia 97 (5): 1111-1121. 
Luque J.D., Sierra E., Torres E., Garcia F. 2006. Cryptovalsa ampeli$n a$ on grapevines in N.E. Spain: identification and pathogenicity. Phytopathology Mediterranea 45 (Suppl.): 101-109.

Moller E.M., Bahnweg G., Geiger H.H. 1992. A simple and efficient protocol for isolation of high molecular weight DNA from filamentous fungi, fruit bodies, and infected plant tissues. Nucleic Acids Results 20 (22): 6115-6116.

Mostert L., Groenewald J.Z., Summerbell R.C., Gams W., Crous P.W. 2006. Taxonomy and pathology of Togninia (Diaporthales) and its Phaeoacremonium anamorphs. Studies of Mycology 54: 1-115.

Mugnai L., Graniti A., Surico G. 1999. Esca (black measles) and brown wood streaking: two old and elusive diseases of grapevines. Plant Disease 83 (5): 404-418.

Phillips A.J.L. 1998. Botryosphaeria dothidea and other fungi associated with excoriose and dieback of grapevines in Portugal. Journal of Phytopathology 146: 327-332.

Phillips A.J.L. 2002. Botryosphaeria species associated with diseases of grapevines in Portugal. Phytopathology Mediterranea 41 (1): 3-18.

Schoeneweiss D.F. 1975. Predisposition, stress and plant disease. Annual Review of Phytopathology 13: 193-211.

Schoeneweiss D.F. 1983. Drought predisposition to Cytospora canker in blue spruce. Plant Disease 67: 383-385.

Sinclair W.A., Lyon H.H., Johnson W.T. 1987. Diseases of Trees and Shrubs. Cornell University Press Ithaca, NY, USA, $680 \mathrm{pp}$.

Tamura K., Nei M., Kumar S. 2011. MEGA5: Molecular evolutionary genetics analysis using maximum likelihood, evo- lutionary distance, and maximum parsimony methods. Molecular Biology and Evolution 28 (10): 2731-2739.

Taylor A., Hardy G.E.S., Wood P., Burgess T. 2005. Identification and pathogenicity of Botryosphaeria species associated with grapevine decline in Western Australia. Australasian Plant Pathology 34 (2): 187-195.

Trouillas F.P., Gubler W.D. 2010. Pathogenicity of Diatrypaceae species in grapevines in California. Plant Disease 94 (7): 867-872.

Van Niekerk J.M., Bester W., Halleen F., Crous P.W., Fourie P.H. 2011. The distribution and symptomatology of grapevine trunk disease pathogens are influenced by climate. Phytopathology Mediterranea 50: S98-S111.

Van Niekerk J.M., Crous P.W., Groenewald J.Z., Fourie P.H., Halleen F. 2004. DNA phylogeny, morphology and pathogenicity of Botryosphaeria species on grapevines. Mycologia 96 (4): 781-798.

Van Niekerk J.M., Groenewald J.Z., Farr D.F., Fourie P.H., Halleen F., Crous P.W. 2005. Reassessment of Phomopsis species on grapevines. Australasian Plant Pathology 34 (1): 27-39.

Vilgalys R., Hester M. 1990. Rapid genetic identification and mapping of enzymatically amplified ribosomal DNA from several Cryptococcus species. Journal of Bacteriology 172 (8): 4238-4246.

White T.J., Bruns T., Lee S., Taylor J. 1990. Amplification and direct sequencing of fungal ribosomal RNA genes for phylogenetics. p. 315-322. In: "PCR Protocols: a Guide to Methods and Applications" (M. Innis, D. Gelfand, J. Sninsky, T. White, eds.). Academic Press, Orlando, Florida, 482 pp. 